\title{
NFKBIZ Gene
}

National Cancer Institute

\section{Source}

National Cancer Institute. NFKBIZ Gene. NCI Thesaurus. Code C150025.

This gene plays a role in the regulation of nuclear factor kappa-B-mediated gene transcription. 